Hochhut · Die Moschee Nûruosmâniye 
ISLAMKUNDLICHE UNTERSUCHUNGEN · BAND 130

\author{
herausgegeben \\ von \\ Klaus Schwarz
}




\section{Pia Hochhut}

\section{Die Moschee Nûruosmâniye in Istanbul}

Beiträge zur Baugeschichte nach osmanischen Quellen 
Alle Rechte vorbehalten.

Ohne ausdrückliche Genehmigung des Verlages ist es nicht gestattet, das Werk oder einzeine Teile daraus nachzudrucken oder zu vervielfältigen.

c Dr. Klaus Schwarz, Berlin 1985

ISBN 3-922968-52-x

Druck: aku-Fotodruck GmbH, Eckbertstr. 19, 8600 Bamberg 